\title{
Differing Mechanisms of Death Induction by Fluorinated Taxane SB-T-12854 in Breast Cancer Cells
}

\author{
MICHAEL JELINEK ${ }^{1}$, ADELA KABELOVA ${ }^{1}$, JAN SRAMEK $^{1}$, JOSHUA SEITZ ${ }^{2}$, IWAO OJIMA ${ }^{2}$ and JAN KOVAR ${ }^{1}$ \\ ${ }^{1}$ Department of Cell and Molecular Biology, Third Faculty of Medicine, Charles University, Prague, Czech Republic; \\ ${ }^{2}$ Institute of Chemical Biology and Drug Discovery, State University of New York at Stony Brook, Stony Brook, NY, U.S.A.
}

\begin{abstract}
Background/Aim: Classical taxanes are routinely used in cancer therapy. In this study, mechanisms involved in death induction by the novel fluorine-containing taxane SB-T-12854 were investigated. Materials and Methods: We employed breast cancer SK-BR-3, MCF-7 and T47D cell lines to assess activation of individual caspases, changes in the expression of proteins of the Bcl-2 family, and the release of pro-apoptotic factors from mitochondria into the cytosol after SB-T-12854 treatment. Results: Caspase-2, -8, and -9 were activated in SK-BR-3 and MCF-7 cells. Only caspase8 was activated in T47D cells. Caspase-7 and -6 were activated in all tested cells while caspase-3 was activated only in SK-BR-3 cells. Pro-apoptotic Bad protein seems to be important for cell death induction in all tested cells. Antiapoptotic Bcl-2 and pro-apoptotic Bim, Bok, Bid and Bik seem to be also associated with cell death induction in some of the tested cells. The mitochondrial apoptotic pathway was significantly activated in association with the release of cytochrome $c$ and Smac from mitochondria, but only in SKBR-3 cells, not in MCF-7 and T47D cells. Conclusion: Cell death induced by SB-T-12854, in the tested breast cancer cells, differs regarding activation of caspases, changes in levels of pro-apoptotic and anti-apoptotic proteins of the Bcl2 family and activation of the mitochondrial apoptotic pathway.
\end{abstract}

Taxanes are well known mitotic poisons used in the treatment of solid tumors. Currently two taxanes, i.e. paclitaxel $\left(\right.$ Taxol $\left.^{\circledR}\right)$ and docetaxel $\left(\right.$ Taxotere ${ }^{\circledR}$ ) are routinely used in chemotherapy of breast, ovary, lung, and other cancers (1-3). Taxanes bind tubulin dimers and block de-

Correspondence to: Dr. Jan Kovář, Department of Cell and Molecular Biology, Third Faculty of Medicine, Charles University, Ruská 87, 10000 Prague 10, Czech Republic. Tel: +420 267102658, Fax: +420 267102650, e-mail: jan.kovar@1f3.cuni.cz

Key Words: SB-T-12854, breast cancer cells, caspases, Bcl-2 proteins, cytochrome $c$ release. polymerization of microtubules (4). The hyperpolymerization of microtubules blocks the cell cycle in the $\mathrm{G}_{2} / \mathrm{M}$ interphase and leads to mitotic arrest $(5,6)$. Subsequently, mitotic arrest usually results in apoptosis induction. However, other alternative pathways leading to cell death can be induced in cells treated with taxanes (7-10).

Pro-apoptotic Bax, Bak and Bok proteins of the Bcl-2 family form channels in the outer mitochondrial membrane and thus enable the release of cytochrome $c$ into the cytosol (11). The level of Bax was found to increase, and the level of Bak was observed to decrease as well as to increase after taxane application (11-13). The role of the Bok protein remains somewhat unclear. Similarly, the levels of antiapoptotic proteins of the Bcl-2 family, such as Bcl-2 and $\mathrm{Bcl}-\mathrm{xL}$ (they prevent formation of Bax/Bak channels in mitochondrial membrane), have been reported to be increased as well as decreased after taxane application (11, $12,14,15)$. In addition, apoptosis induced by taxanes is usually associated with Bcl-2 phosphorylation (16). Proapoptotic $\mathrm{BH} 3$-only proteins of the $\mathrm{Bcl}-2$ family, that suppress the activity of anti-apoptotic $\mathrm{Bcl}-2$ proteins, can effectively induce the intrinsic mitochondrial pathway of apoptosis induction (17-19). There are reports showing Bim protein to be directly involved in cell death induction by taxanes (20-21). Furthermore, some roles for Bad, Bik and Puma in cell death induction by taxanes in breast cancer cells have been reported $(11,17,22)$.

Cytochrome $c$ and Smac protein release from mitochondria are fundamentally important for the activation of the mitochondrial apoptotic pathway and activation of caspases. The release of cytochrome $c$ and/or Smac occurrs in vitro and in vivo in cancer cells treated with taxanes (23-25). On the other hand, cell death induced by taxanes in cancer cells can also be realized without release of cytochrome $c$ (24).

Concerning caspases, the activation of caspase- 8 , the main initiator caspase of the extrinsic pathway of apoptosis induction, and caspase-9, the main initiator caspase of the intrinsic mitochondrial pathway of apoptosis induction, have been observed in various cell types after taxane treatment $(7$, 15, 26, 27). Recently, several groups including ours have 
reported that caspase-2, a highly conservative protease involved in cell death induction by different stimuli (28), appears to play an important role in taxane-induced cell death (29-31). Executioner caspase-3, -7 and -6 have also been activated after taxane application in various types of cancer cells $(7,12,32)$. Caspase- 3 probably plays the most important role here, while caspase- 6 and -7 seem to have minor roles $(23,32)$.

There is an abundance of data concerning cell death induction by novel taxanes $(6,7,24,31,32)$. However, the precise roles of some components of the apoptosis-inducing pathways (Bcl-family proteins, mitochondria, and caspases) have not yet been elucidated.

Because innate or acquired resistance of cancer cells to clinically used taxanes remains a problem in chemotherapy (33), novel taxanes have been developed to overcome resistance (34-37). Some of these novel taxanes have proven to be significantly more effective than the classical taxanes in cell death induction in resistant cancer cells $(7,38)$.

We previously reported that novel fluorine-containing taxanes are effective in cell death induction in cancer cells as well as in cancer cells resistant to paclitaxel (7). In the present study, we showed that the novel fluorine-containing taxane SB-T-12854 (39) is effective in cell death induction in tested breast cancer cell lines SK-BR-3, MCF-7 and T47D. However, mechanisms of cell death induction seem to differ in these cells based on the observed changes in the expression of the Bcl-2 family proteins, the release of proapoptotic factors from mitochondria, and activation of caspases.

\section{Materials and Methods}

Materials. SB-T-12854 (39) was synthesized in the laboratory of Professor Iwao Ojima at the Institute of Chemical Biology and Drug Discovery (Stony Brook, NY, USA). For the structures of SB-T12854 and classical paclitaxel see Figure 1. The taxane was dissolved in DMSO (tissue culture quality) to obtain a $1 \mathrm{mM}$ stock solution. For western blot analysis, the following primary antibodies were used: rabbit monoclonal antibody against Bid (ab32060) and Bok (ab186745) from Abcam (Cambridge, UK), rabbit polyclonal antibody against Bad (\#9292), Bax (\#5023), Bik (\#4592), and Bok (\#4521), rabbit monoclonal antibody against Bcl-xL (\#2764) and Bim (\#2933), rabbit polyclonal antibody against cleaved caspase-3 (\#9661), cleaved caspase-6 (\#9761) and cleaved caspase-7 (\#9491), rabbit monoclonal antibody against cleaved caspase-8 (\#9496), rabbit polyclonal antibody against cleaved caspase-9 (\#9505), rabbit polyclonal antibody against COX IV (\#4844) and cytochrome $c$ (\#4272) and mouse monoclonal antibody against Smac/Diablo (\#2954) from Cell Signaling Technology (Danvers, MA, USA), mouse monoclonal antibody against Bax (sc-7480) and Bcl-2 (sc7382) from Santa Cruz Biotechnology, INC. (Dallas, TE, USA), rat monoclonal antibody against caspase-2 (ALX-804-356-C100) from Enzo Life Sciences (Farmingdale, NY, USA), and mouse monoclonal antibody against actin (AC-40, A3853) from SigmaAldrich.
Cells and culture conditions. Human breast carcinoma cell lines SKBR-3, MCF-7, and T47D were obtained from American Type Culture Collection (ATCC, Rockville, MD, USA), the National Cancer Institute (Frederick, MD, USA), and the European Collection of Cell Cultures (ECCC, Porton Down, Salisbury, UK), respectively. SK-BR3 adenoma cells are without functional p53, with functional caspase3 , and they overexpress Her2/Neu receptor. MCF-7 adenoma cells are with functional p53, without functional caspase-3 (40), and they carry progesterone and estrogen receptors. T47D ductal cells are without functional $\mathrm{p} 53$, with functional caspase-3, and they carry progesterone and estrogen receptors. These cell lines represent cells with differing status of key molecules and thus it helps elucidate various mechanisms involved in cell death induction. The basic medium was RPMI 1640 (Sigma-Aldrich, St. Louis, MO, USA) containing extra L-glutamine (300 $\mu \mathrm{g} / \mathrm{ml})$, sodium pyruvate $(110 \mu \mathrm{g} / \mathrm{ml})$, HEPES $(15 \mathrm{mM})$, penicillin $(100 \mathrm{U} / \mathrm{ml})$ and streptomycin $(100 \mu \mathrm{g} / \mathrm{ml})(41)$. The culture medium consisted of basic medium supplemented with $10 \%$ heatinactivated fetal bovine serum (Biochrom AG, Berlin, Germany). The cells were maintained in a culture medium at $37^{\circ} \mathrm{C}$ in a humidified atmosphere of $5 \% \mathrm{CO}_{2}$ in air. For experiments, taxanes were diluted in culture medium to achieve the required concentrations. Culture medium without taxane was used as controls.

Assessment of cell growth and survival. Cells were harvested and seeded at $20 \times 10^{3}$ cells $/ 100 \mu$ l of culture medium into wells of $96-$ well plastic plates. After a $24-\mathrm{h}$ pre-incubation period, allowing cells to attach, the culture medium was replaced by either culture medium without taxane (control) or medium with tested taxane at the desired concentrations. Cell growth and survival were evaluated $96 \mathrm{~h}$ after taxane application. The number of living cells was determined using a hemocytometer after staining with trypan blue.

Preparation of cell lysates. Cells at desired concentrations were seeded in Petri dishes or culture flasks and taxane was added after a 24-h pre-incubation period. After the incubation period, cells were harvested by low-speed centrifugation $\left(2,000 \mathrm{rpm}, 9 \mathrm{~min}, 4^{\circ} \mathrm{C}\right)$, washed in PBS and centrifuged again. Cell pellets were stored at $-80^{\circ} \mathrm{C}$. Next, pellets were re-suspended in RIPA buffer (Sigma Aldrich, St. Louis, MO, USA) containing a $1 \%$ mixture of protease inhibitors (P8340, Sigma Aldrich). Protein lysates were centrifuged $\left(14,000 \mathrm{rpm}, 20 \mathrm{~min}, 4^{\circ} \mathrm{C}\right)$ and the supernatants containing proteins were stored at $-80^{\circ} \mathrm{C}(24)$.

Cell fractionation. Cells (approximately $3.6 \times 10^{6}$ cells per sample) were seeded into Petri dishes or culture flasks and taxanes were added after a 24-h pre-incubation. After the incubation period, cells were harvested by low-speed centrifugation $(2,000 \mathrm{rpm}, 9 \mathrm{~min}$, $4^{\circ} \mathrm{C}$ ), washed in PBS and centrifuged again. Cell pellets were resuspended in a specific lysis buffer $\left(75 \mathrm{mM} \mathrm{NaCl}, 1 \mathrm{mM} \mathrm{NaH} \mathrm{PO}_{4}\right.$, $8 \mathrm{mM} \mathrm{Na} 2 \mathrm{HPO}_{4}, 250 \mathrm{mM}$ sucrose, and $1 \%$ mixture of protease inhibitors P8340 from Sigma Aldrich, St. Louis, MO, USA) containing $0.635 \mathrm{mM}$ digitonin D141 (Sigma-Aldrich) and vortexed for $60 \mathrm{~s}$. Lysates were than centrifuged $\left(14,000 \mathrm{rpm}, 1 \mathrm{~min}, 4^{\circ} \mathrm{C}\right)$ and supernatants (containing cytosolic fractions) were removed and stored at $-80^{\circ} \mathrm{C}$. The specific lysis buffer described above, but containing $6.35 \mathrm{mM}$ digitonin D141 (Sigma-Aldrich), was added to the pellets and suspensions were mixed for $60 \mathrm{~s}$ and centrifuged $\left(14,000 \mathrm{rpm}, 1 \mathrm{~min}, 4^{\circ} \mathrm{C}\right)$. After centrifugation, supernatants (containing mitochondrial fractions) were stored at $-80^{\circ} \mathrm{C}$. Cell fractions were analyzed using western blot. 


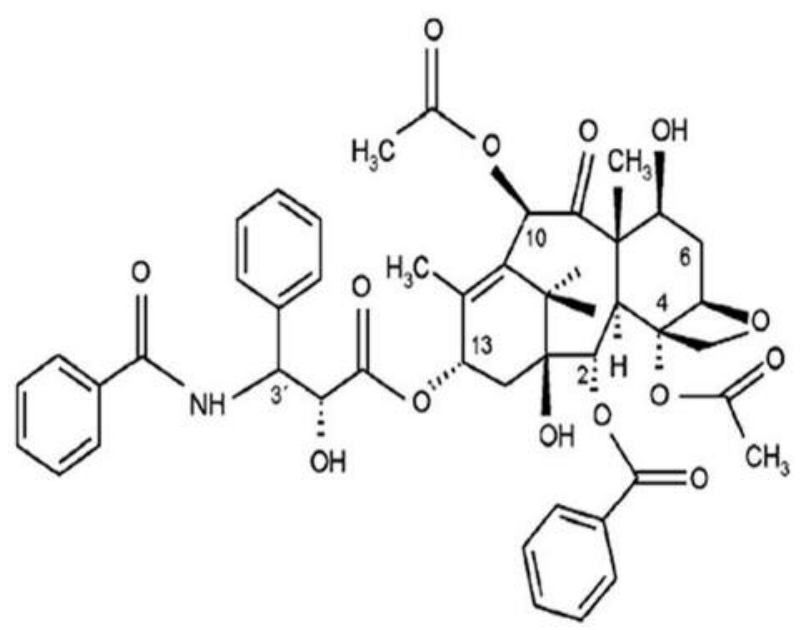

Paclitaxel

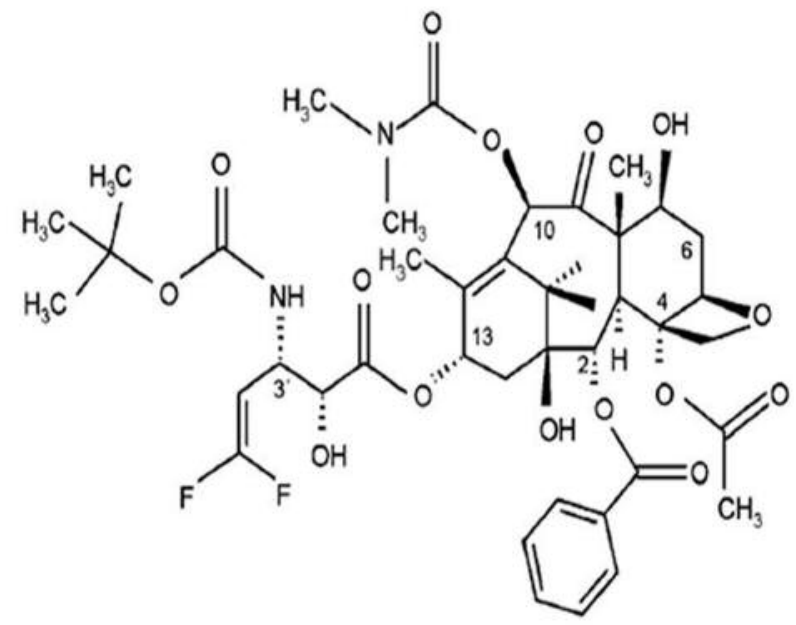

SB-T-12854

Figure 1. Chemical structures of paclitaxel and SB-T-12854.

Western blot analysis. Concentration of proteins in cell lysates and cell fractions were assessed using the BCA Protein Assay Reagent from Pierce (Thermo Fisher Scientific, Rockford, IL, USA). Depending on protein concentrations, cell lysates and cell fractions were diluted in RIPA buffer to the gel loading concentration of proteins $(2 \mu \mathrm{g} / \mu \mathrm{l})$, mixed with equal volumes of sample buffer $(0.125 \mathrm{M}$ Tris/ $\mathrm{HCl} \mathrm{pH} 6.8,10 \%$ glycerol, $4 \%$ SDS, $0.25 \mathrm{M}$ DTT $)$ and heated for $5-7 \mathrm{~min}$ at $110^{\circ} \mathrm{C}$. Protein samples were separated using protein electrophoresis (Bio-Rad, Hercules, CA, USA). Proteins separated by SDS-PAGE were blotted onto a $0.2 \mu \mathrm{m}$ PROTRAN BA 83 nitrocellulose membrane (Whatman-Schleicher and Schuell, Maidstone, UK) for $3 \mathrm{~h}$ at $0.25 \mathrm{~A}$, using a MiniProtean II blotting apparatus (Bio-Rad). The membrane was blocked with $5 \%$ non-fat dry milk or 5\% BSA in TBS for 15-20 min and incubated with the primary antibody at $4^{\circ} \mathrm{C}$ overnight. After the incubation, the membrane was washed three times (5-10 $\mathrm{min}$ ) with TBS containing $0.1 \%$ Tween-20. Then it was incubated for $1-2 \mathrm{~h}$ with the corresponding horseradish peroxidase-conjugated secondary antibody (Santa Cruz Biotechnology, Santa Cruz, CA, USA). Afterward, the membrane was washed (as described above) and the chemiluminescence signal was detected using Supersignal reagents from Pierce (Thermo Fisher Scientific) and a CCD device (Carestream).

\section{Results}

Effect of fluorinated taxane SB-T-12854 on growth and survival. We assessed the effect of fluorine-containing taxane SB-T12854 (Figure 1) on cell growth and survival in breast cancer SK-BR-3, MCF-7 and T47D cells (see Materials and Method section) at wide range of concentrations (0.1-3,000 nM). In SKBR-3 cells, SB-T-12854 induced cell death at a concentration of $30 \mathrm{nM}$ and higher concentrations. $\mathrm{C}_{50}$ (concentration of taxane resulting in $50 \%$ of living cells relative to controls after $96 \mathrm{~h}$ of incubation) for SK-BR-3 cells was determined to be approximately $4 \mathrm{nM}$. In MCF-7 cells, the taxane also induced cell death at a concentration of $30 \mathrm{nM}$ and higher concentrations. $\mathrm{C}_{50}$ for MCF-7 cells was also about $4 \mathrm{nM}$. Similar data were obtained with T47D cells. SB-T-12854 induced cell death at a concentration $\geq 30 \mathrm{nM}$ and the $\mathrm{C}_{50}$ was approximately $5 \mathrm{nM}$ (Figure 2).

In further experiments, we used the death inducing concentration, i.e. the lowest concentration with near maximum death-inducing effect, $100 \mathrm{nM}$ of SB-T-12854 for SK-BR-3 cells and $600 \mathrm{nM}$ for MCF-7 cells. For T47D cells, we used $300 \mathrm{nM}$ because concentrations with a near maximum death-inducing effect were extremely high (Figure 2).

Effect of SB-T-12854 on activation of caspases. We used western blot analysis in order to assess the activation of caspase-2, -8, -9, -3, -7, and -6 after application of SB-T12854 at the death-inducing concentration in tested cell lines. Caspase activation was assessed by detecting the cleaved forms of caspases (see Materials and Methods section). Cleaved caspase-2, cleaved caspase- 8 and cleaved caspase9 appeared in significant amounts $36 \mathrm{~h}$ after taxane treatment in SK-BR-3 cells. Lower levels of cleaved caspase- 8 and -9 were observed after only $24 \mathrm{~h}$. As for executioner caspases, we detected high levels of cleaved caspase- 3 and -7 after $36 \mathrm{~h}$. Lower levels of cleaved caspase- 3 and -7 were also observed after $24 \mathrm{~h}$. Similarly, cleaved caspase- 6 was detected $36 \mathrm{~h}$ after taxane treatment (Figure 3). In MCF-7 cells, the level of cleaved caspase- 2 significantly increased $36 \mathrm{~h}$ after SB-T-12854 application. However, after $48 \mathrm{~h}$ the level substantially decreased. Cleaved caspase- 8 was present after 36 as well as $48 \mathrm{~h}$. Cleaved caspase-9 was detected between $24 \mathrm{~h}$ and $48 \mathrm{~h}$ after taxane application. Since there is not functional caspase-3 in MCF-7 cells (40), cleaved caspase-3 was not detected. Low levels of cleaved caspase- 

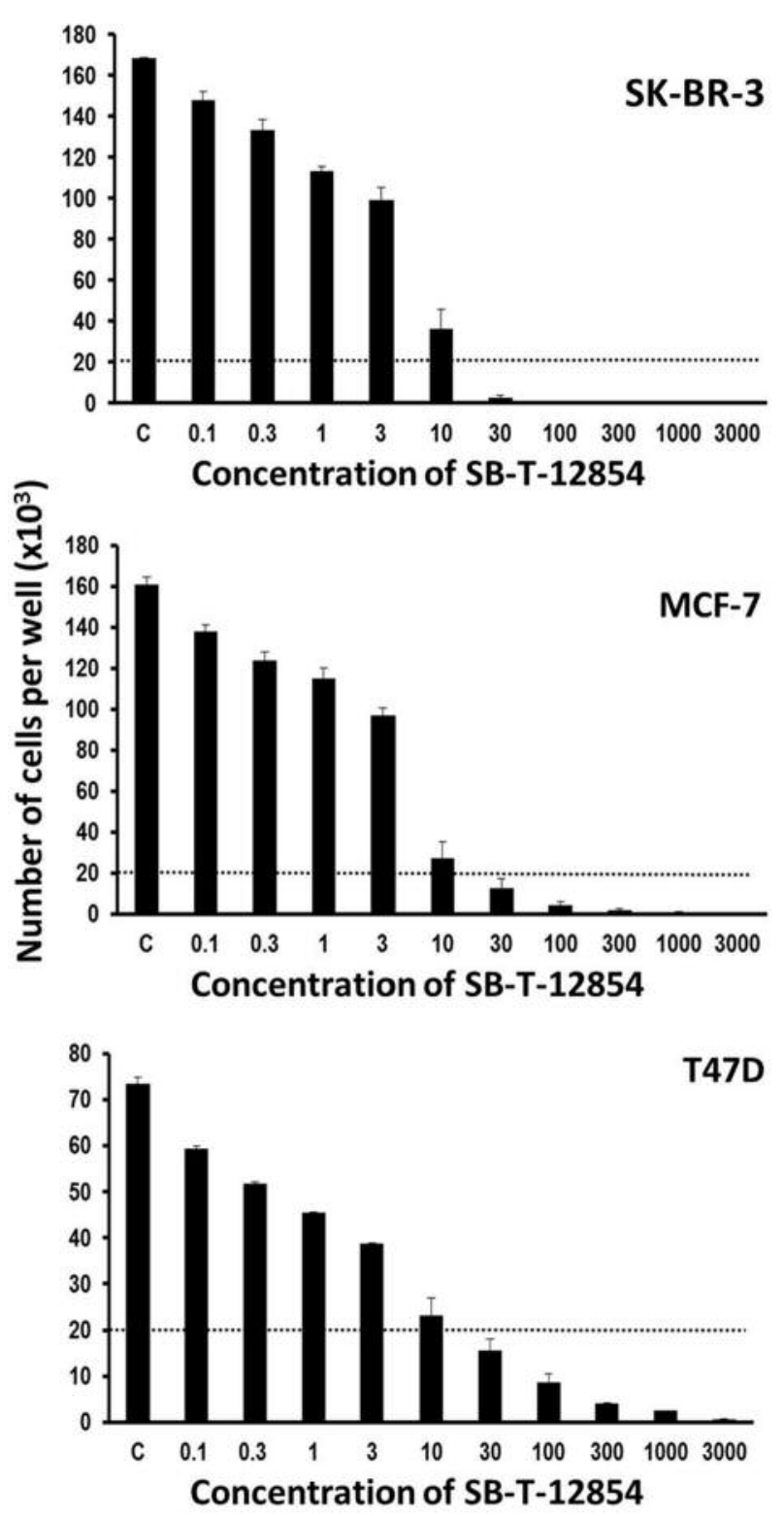

Figure 2. Effect of SB-T-12854 (0.1-3,000 nM) on growth and survival of $S K-B R-3, M C F-7$, and T47D cells. Control cells $(C)$ were incubated without SB-T-12854. The cells were seeded at $20 \times 10^{3}$ cells $/ 100 \mu \mathrm{l}$ of medium per well (dotted line). The number of living cells was determined after $96 h$ of incubation (see Materials and Methods section). Each column represents the mean of two separate cultures \pm SEM

7 were seen after $24 \mathrm{~h}$ with a significant increase after $36 \mathrm{~h}$. However, the level of cleaved caspase- 7 decreased $48 \mathrm{~h}$ after taxane application. Cleaved caspase- 6 was detected $36 \mathrm{~h}$ after taxane treatment with its subsequent decrease in cleaved caspase-6 level (Figure 3). A significant increase of the level of cleaved caspase-2 was not detected in T47D cells after SB-T-12854 application. Concerning caspase-8, the level of cleaved caspase- 8 increased between $72 \mathrm{~h}$ and $120 \mathrm{~h}$ after taxane application. Nearly undetectable levels of cleaved caspase- 9 were observed between $48 \mathrm{~h}$ and $120 \mathrm{~h}$ after taxane treatment. Interestingly, only low levels of cleaved caspase-3 were detected after the treatment. Concerning other executioner caspases, levels of cleaved caspase- 6 as well as caspase-7 were significantly increased $120 \mathrm{~h}$ after SB-T-12854 application (Figure 3).

To summarize, all tested initiator and executioner caspases were activated in SK-BR-3 cells within $36 \mathrm{~h}$. The same was true for MCF-7 cells with the exception of the non-functional caspase-3. In T47D cells, only the activation of caspase- 8 , 7 and -6 was observed.

Effect of SB-T-12854 on levels of proteins of the Bcl-2 family. We measured changes in levels of proteins of the Bcl-2 family in cells after taxane treatment (see Materials and Methods section). The level of pro-apoptotic (channel forming) Bax protein did not change due to SB-T-12854 application, while the level of Bok protein significantly decreased $36 \mathrm{~h}$ after taxane application in SK-BR-3 cells (Figure 4A). The level of anti-apoptotic Bcl-2 protein significantly increased $12 \mathrm{~h}$ after taxane application. Most of proteins seemed to be phosphorylated (phosphorylated form is presented by the upper band of the double band observed). On the other hand, the level of anti-apoptotic Bcl-xL protein did not change significantly (Figure 4B). Concerning the BH3-only proapoptotic proteins of the Bcl-2 family, the level of Bad protein started to increase $12 \mathrm{~h}$ and peaked $24 \mathrm{~h}$ after taxane application. After $36 \mathrm{~h}$ a decrease was seen. The level of Bid protein decreased significantly $36 \mathrm{~h}$ after taxane treatment. The level of Bik seemed to increase $12 \mathrm{~h}$ after taxane treatment and then decreased $24 \mathrm{~h}$ after treatment. Bim level decreased significantly $24 \mathrm{~h}$ after treating with taxane (Figure 4C). In MCF-7 cells, SB-T-12854 did not significantly affect the level of Bax protein. However, the level of Bok protein increased significantly $36 \mathrm{~h}$ after taxane application with a subsequent decrease (Figure 4A). The level of anti-apoptotic $\mathrm{Bcl}-2$ started to increase $12 \mathrm{~h}$ after taxane application. At the same time some of Bcl-2 was phosphorylated. Interestingly, Bcl-2 became significantly dephosphorylated $36 \mathrm{~h}$ after application. The level of Bcl-xL did not change significantly after taxane treatment (Figure 4B). As to the BH3-only proteins, the level of Bad seemed to be slightly increased $24 \mathrm{~h}$ after treatment. We did not observe any change in the level of Bid. Concerning Bik level, it appeared to increase $12 \mathrm{~h}$ after treatment. The level of Bim protein increased 12$24 \mathrm{~h}$ and decreased $36 \mathrm{~h}$ after taxane treatment (Figure 4C). There were no significant changes in the level of Bax and Bok proteins in T47D cells after SB-T-12854 application (Figure 4A). The level of anti-apoptotic Bcl-2 was found to decrease from $72 \mathrm{~h}$ to $96 \mathrm{~h}$ after taxane application. Phosphorylation of 


\section{SK-BR-3}

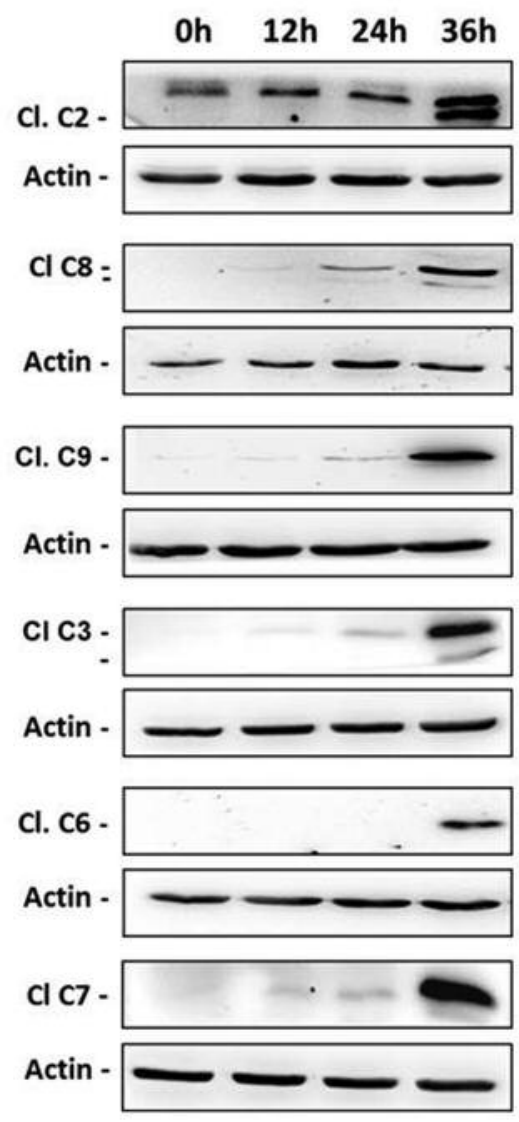

MCF-7

Oh $12 \mathrm{~h} 24 \mathrm{~h} 36 \mathrm{~h} 48 \mathrm{~h}$

Cl. C2 -

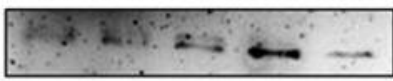

Actin : $-\longrightarrow$

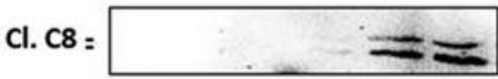

Actin -
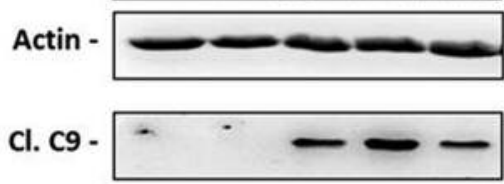

Actin -
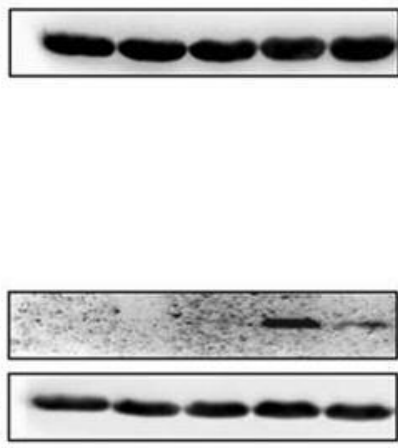

Cl. C7 -

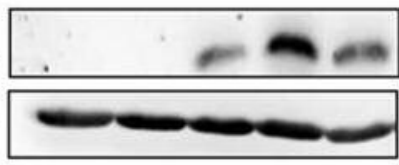

Actin -
T47D

$48 \mathrm{~h} 72 \mathrm{~h} 96 \mathrm{~h} 120 \mathrm{~h}$
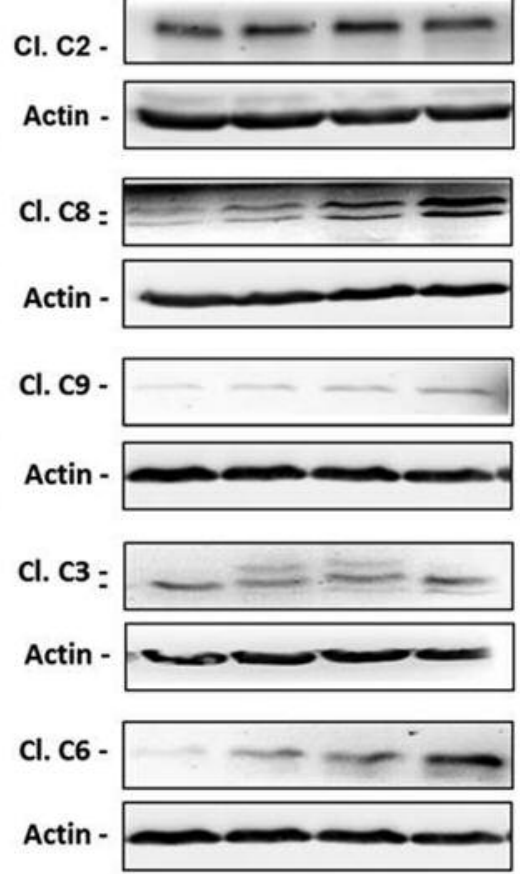

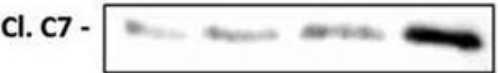

Actin -
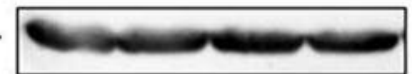

Figure 3. Effect of SB-T-12854 on the activation of caspase-2, -8, -9, -3, -6 and -7 in SK-BR-3, MCF-7, and T47D cells. After incubation period with the death-inducing concentration of SB-T-12854 (0-36 h and $100 \mathrm{nM}$ for SK-BR-3 cells, 0-48 h and $600 \mathrm{nM} \mathrm{for} \mathrm{MCF-7} \mathrm{cells,} 48-120 \mathrm{~h}$ and $300 \mathrm{nM}$ for T47D cells), levels of cleaved forms of caspases were determined using western blot analysis and relevant antibodies (see Materials and Methods section). Actin levels were used to confirm equal protein loading. The data shown were obtained in one representative experiment of two independent experiments.

Bcl-2, which was detected in SK-BR-3 and MCF-7 cells, was not observed in T47D cells. The level of Bcl-xL did not seem to be significantly affected by taxane treatment (Figure 4B). Concerning the $\mathrm{BH} 3$-only proteins, the level of Bad protein started to increase $48 \mathrm{~h}$ after taxane application. The level of Bid protein seemed to decrease $72 \mathrm{~h}$ after taxane application. There was nearly no effect of the taxane on the level of Bik protein. The level of Bim protein was found to increase $48 \mathrm{~h}$ after SB-T-12854 treatment (Figure 4C).

In summary, higher levels of Bcl-2 together with its phosphorylation were detected in SK-BR-3 and MCF-7 after SB-T-12854 application. However, there was no up-regulation and phosphorylation of Bcl-2 in T47D cells. The level of Bad increased in all cell lines after application. The most conspicuous effect was observed in SK-BR-3 cells. Finally, the levels of Bok and Bim seemed to change significantly, but the changes differed in the individual tested cell lines.
Effect of SB-T-12854 on cytochrome $c$ and Smac release from mitochondria. To clarify the involvement of mitochondria in apoptosis induction by SB-T-12854 in the tested cell lines, the release of cytochrome $c$ and Smac protein from mitochondria into the cytosol was assessed using western blot analysis after cell fractionation (see Materials and Methods section). As expected, cytochrome $c$ and Smac were detected in mitochondrial fractions in control SK-BR-3, MCF-7 as well as T47D cells. For SK-BR-3 cells, cytochrome $c$ and Smac, in significant amounts, were detected in the cytosolic fraction $36 \mathrm{~h}$ after SB-T-12854 treatment at death-inducing concentration. We observed small amounts of cytochrome $c$ in the cytosolic fraction of MCF-7 cells 36-48 h after taxane treatment, albeit it was not a significant release. We did not detect any release of cytochrome $c$ or Smac into the cytosol of T47D cells after taxane treatment (Figure 5). 


\section{SK-BR-3}

A

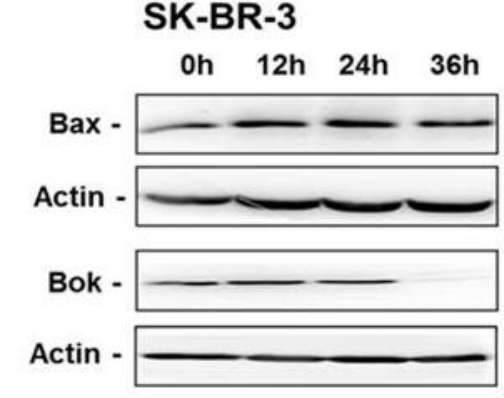

B

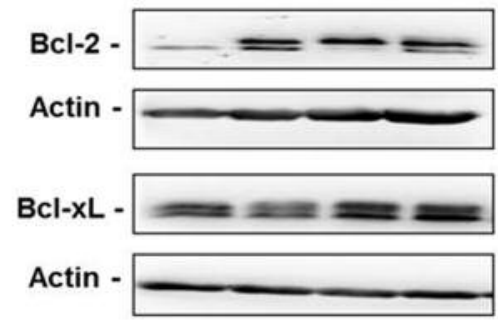

C
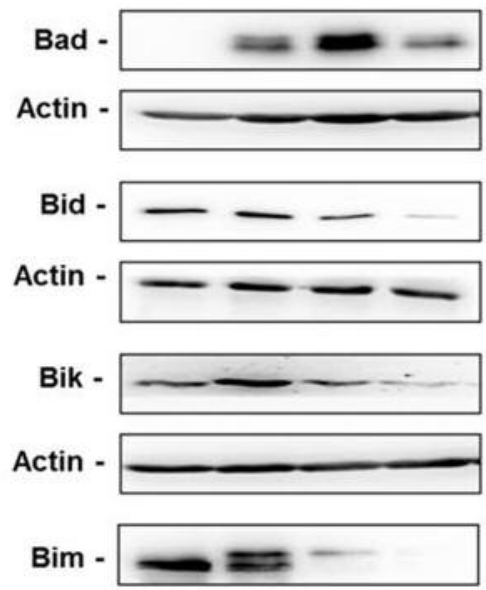

Actin

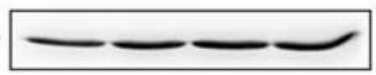

\section{MCF-7}

Oh $\quad 12 \mathrm{~h} \quad 24 \mathrm{~h} \quad 36 \mathrm{~h} 48 \mathrm{~h}$
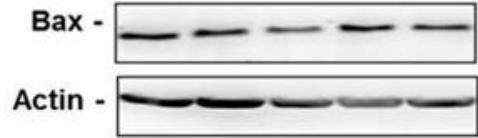

Bok -

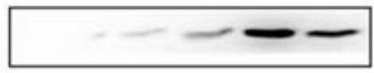

Actin -

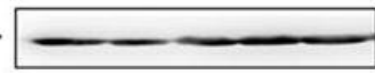

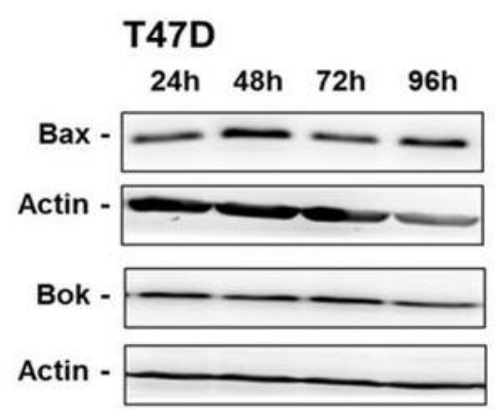

$\mathrm{Bcl}-2$ -

Actin -

$\mathrm{BCl}-\mathrm{xL}$ -
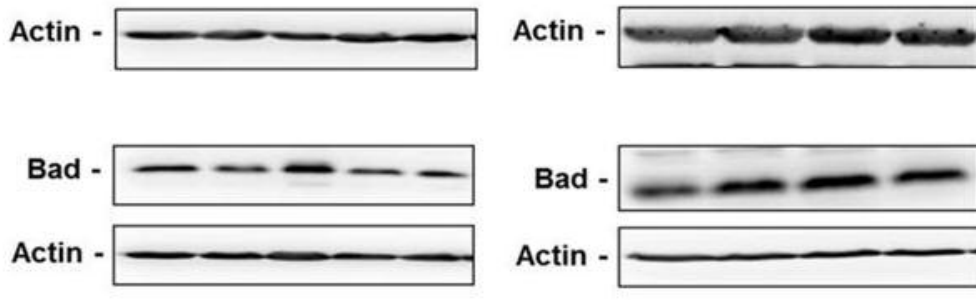

Bid -
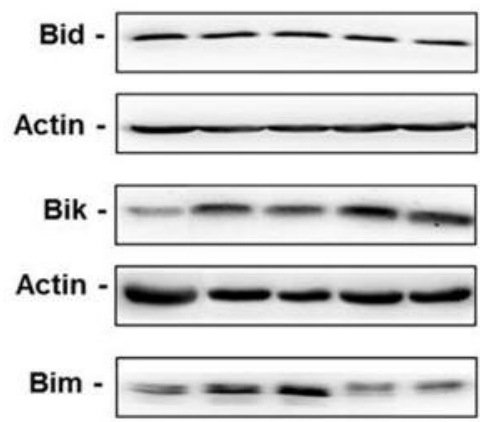

Actin -

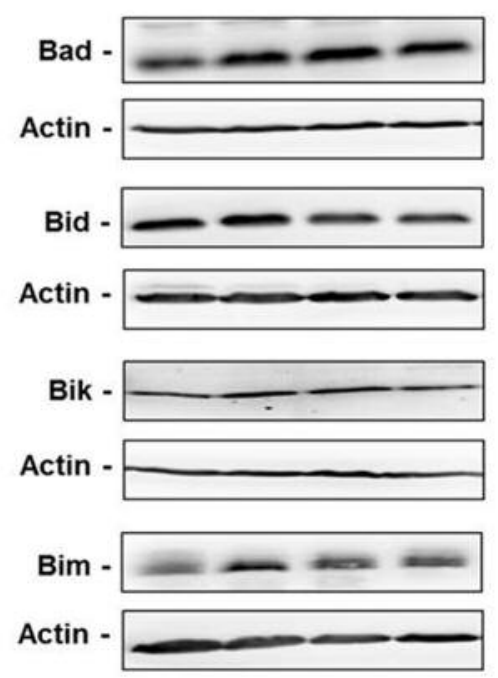

Figure 4. Effect of SB-T-12854 on the level of proteins of the Bcl-2 family in SK-BR-3, MCF-7, and T47D cells, i.e. (A) proapoptotic proteins of the Bax subfamily, $(B)$ antiapoptotic proteins of the Bcl-2 subfamily and $(C)$ proapoptotic proteins of the BH3-only subfamily. After the incubation period with the death-inducing concentration of SB-T-12854 (0-36 h and $100 \mathrm{nM}$ for SK-BR-3 cells, 0-48 h and $600 \mathrm{nM}$ for MCF-7 cells, 24-96 h and 300 $n M$ for T47D), levels of the proteins were determined using western blot analysis and relevant antibodies (see Materials and Methods section). Actin levels were used to confirm equal protein loading. The data shown were obtained in one representative experiment of two independent experiments.

Thus, the mitochondrial pathway seems to play an important role in apoptosis induction in SK-BR-3 cells, but not in MCF-7 and T47D cells.

\section{Discussion}

In our previous studies on the mechanisms of cell death induction by taxanes in breast cancer cells, we reported that during cell death induction by taxanes caspase- 2 was involved as the apical caspase and its activation results in the mutual activation of caspase- 3 and $-7(31,32)$. In the present study we investigated molecular mechanisms of cell death induction by novel fluorinated taxane SB-T-12854 (39) in breast cancer cells. We used SK-BR-3 and T47D cells (without functional p53) and MCF-7 cells (without functional caspase-3) (see Materials and Methods section). 
SB-T-12854 induced cells death in breast cancer cell lines examined (Figure 2). The taxane has also been shown to be effective in cell death induction in other cancer cell lines (7, 42). The effect of SB-T-12854 on the growth and survival of breast cancer cells was similar to the effect of previously studied novel non-fluorinated taxane SB-T-1216 (31, 32). Compared to SB-T-1216, the fluorine atoms in the structure of SB-T-12854 are supposed to increase the resistance of the taxane molecule to metabolization (42). Interestingly, both taxoids SB-T-12854 and SB-T-1216 were able to overcome the acquired resistance of breast cancer cells to paclitaxel (7, 43). Thus, SB-T-12854 seems to be a promising agent for induction of cell death in sensitive as well as resistant breast cancer cells.

Initiator and executioner caspases have been found to be activated in many types of cancer cell lines after the application of classical as well as novel taxanes $(7,12,27$, $31,44)$. Activation of individual caspases seems to be cell type and also applied taxane specific. Therefore, we focused on the activation of all initiator and executioner caspases, except of caspase-10. In this study, we found that SB-T12854 activated initiator caspase- 8 , caspase- 9 and caspase- 2 in SK-BR-3 and MCF-7 cells (Figure 3). Previously we have reported the activation of caspase- 2 in breast cancer cells after taxane application, but this activation was not associated with PIDDosome formation (31). We detected a significant release of cytochrome $c$ into the cytosol only in SK-BR-3 cells, but not in MCF-7 cells after SB-T-12854 treatment. Therefore, we suggest that activation of caspase9 in MCF-7 cells could result from direct activation by caspase-2 (32). Interestingly, caspase-8 was the only initiator caspase activated significantly in T47D cells (see Figure 3). Concerning the mechanism of activation of caspase- 8 , it seems different from the previously described non-receptor activation of caspase- 8 by caspase-3 (26) or by caspase- 2 (32) since we did not observe significant activation of caspase- 3 or caspase- 2 in T47D cells. It seems that the role of caspase- 8 in apoptosis induction after taxane treatment in T47D cells is more important than that in SK-BR-3 and MCF-7 cells as discussed previously (32).

Caspase- 3 was significantly activated only in SK-BR-3 cells, taking into account the fact that there is not functional caspase3 in MCF-7 cells. On the other hand, caspase- 7 and caspase- 6 were activated in all tested cells. The activation of executioner caspases has obviously been described after taxane application previously $(12,26,32,44)$ and caspase-3 was usually the most important cell death inducer. Caspase- 3 is known as the executioner caspase functioning upstream of caspase-7 and caspase-6. This fact led to a question. How are caspase-7 and caspase- 6 activated in MCF-7 and T47D cells? It is possible that initiator caspases, such as caspase- 2 or caspase- 8 , are somehow involved. It seems that the activation of caspases induced by SB-T-12854 in SK-BR-3 and MCF-7 cells follows
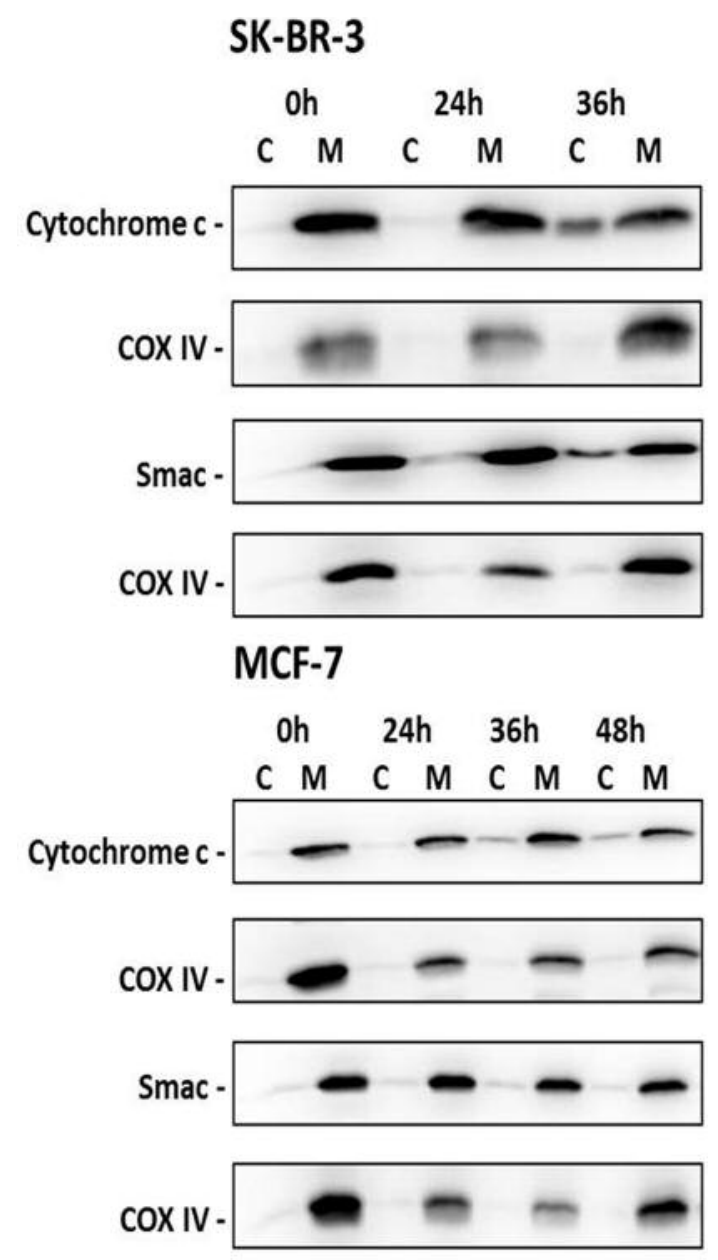

T47D
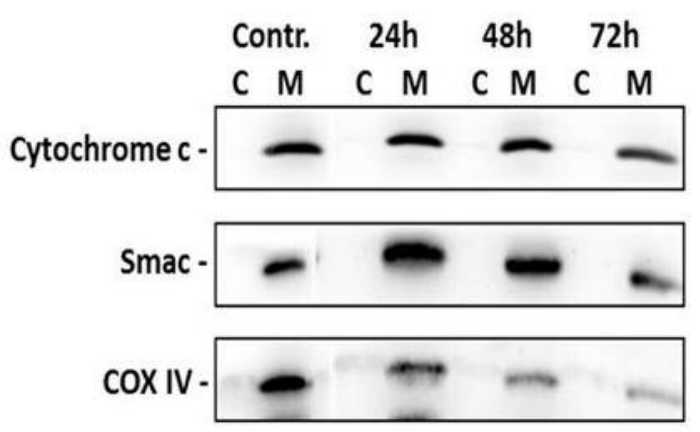

Figure 5. Effect of SB-T-12854 on the release of cytochrome c and Smac protein from mitochondria in SK-BR-3, MCF-7, and T47D cells. After incubation period with the death-inducing concentration of SB-T-12854 (0-36 $h$ and $100 \mathrm{nM}$ for SK-BR-3 cells, 0-48 h and $600 \mathrm{nM}$ for MCF-7 cells, 24-72 $h$ and $300 \mathrm{nM}$ for T47D cells), levels of cytochrome c and Smac were determined in mitochondrial $(M)$ and cytosolic $(C)$ fractions using western blot analysis and relevant antibodies (see Materials and Methods section). Cells incubated in taxane-free medium for $24 \mathrm{~h}$ (Control) were used as control for T47D cells. COX IV (integral mitochondrial protein) level was used to confirm proper fractionation. The data shown were obtained in one representative experiment of two independent experiments. 
a previously proposed scheme (32). The activation of caspases seems to differ in T47D cells. In particular, caspase-8 may play a more important role here (see above).

Proteins of the Bcl-2 family are known to play an important role in taxane-induced cell death in many types of cancer cells $(12,21,22,45)$. Concerning proteins of the Bcl-2 family, we decided to test channel-forming Bax protein and less studied Bok protein. Anti-apoptotic Bcl-2 and Bcl-xL proteins were selected according to our preliminary data. Selected Bad, Bid, Bik and Bim proteins from the BH3-only subfamily had been previously reported to have potential functions in cell death induction by taxanes. As for the channel forming pro-apoptotic proteins of this family, Bok expression increased after SB-T12854 treatment in MCF-7 cells, showing a possible role in cell death induction in these cells (Figure 4A). As far as we know, there are no data in the literature demonstrating the role of Bok in taxane-induced cell death in breast cancer cells. Interestingly, Bok has been reported to be important in cell death induction after blocking the cell cycle (46), which results from taxane treatment. However, there was no significant increase in Bok levels in SK-BR-3 and T47D cells and thus Bok does not seem to play a key role in cell death induction by SB-T-12854 in breast cancer cells.

Considering anti-apoptotic proteins of the Bcl-2 family, we observed increased levels of Bcl-2 in SK-BR-3 and MCF-7 cells after SB-T-12854 application. In addition, Bcl2 was phosphorylated in both cell lines after taxane application. In T47D cells, the level of Bcl-2 decreased after SB-T-12854 treatment and there was no significant phosphorylation of Bcl-2 (Figure 4B). Increased level of Bcl2 has been previously shown to be protective cells against the effect of taxanes (12). However, some contra-indicatory data exist concerning the role of Bcl-2 in taxane effect (14). We suggest that increased levels of Bcl-2 followed by its phosphorylation could represent some type of protective mechanism of SK-BR-3 and MCF-7 cells against taxane effect. The situation seems to be different in T47D cells, where decreasing levels of Bcl-2 after taxane application correlated with cell death induction (Figure 4B).

As for the BH3-only proteins of the Bcl-2 family, the level of Bad was found to be more or less transiently increased in all tested cells (Figure 4C). Apoptosis induction by taxanes has been shown to be associated with the pro-apoptotic activity of Bad protein (12). Furthermore, the involvement of Bad in the regulation of cell-cycle progress associated with cell death induction has also been demonstrated (22). We assume that Bad is, directly or indirectly, involved in cell death induction by SB-T-12854. The level of Bim was transiently higher in MCF-7 and T47D cells after SB-T12854 application (Figure 4C). Bim protein can induce cell death by affecting $\mathrm{Bcl}-2$ protein during cytoskeleton stress, however, recently other indirect mechanisms of cell death induced by Bim that were associated with mitotic aberrations have been described $(21,45,47)$. This could also be the case of tested MCF-7 and T47D cells. However, Bim levels were significantly decreased after taxane application in SK-BR-3 cells (Figure 4C). Similarly, a decrease of Bik and Bid levels was also found in SK-BR-3 cells after SB-T-12854 application. The relationship between the decrease and cell death induction remains unclear.

Previously we and other groups have reported that cell death dependent on as being well as independent of cytochrome $c$ release from mitochondria into the cytosol. It means dependence on or independence from mitochondrial the apoptotic pathway $(24,44)$. Thus, we tested activation of this crucial pathway of apoptosis induction. Significant release of cytochrome $c$ and Smac into the cytosol after SBT-12854 application was only observed in SK-BR-3 cells (Figure 5). Thus, it is likely that caspase-9 is activated by an alternative mechanism unrelated to the classical mitochondrial apoptotic pathway in MCF-7 cells. We suggest that the mitochondrial apoptotic pathway is activated only in SK-BR-3 cells after taxane application and it is not required for cell death induction in MCF-7 and T47D cells.

We can conclude that the novel taxane SB-T-12854 induces cell death effectively in SK-BR-3, MCF-7 and T47D breast cancer cells. The activation of initiator caspase-2, $-8,-9$, in SK-BR-3 and MCF-7 cells and caspase- 8 in T47D cells, as well as activation of executioner caspase-3 in SK-BR-3 cells and caspase-7, -6 in all tested cell lines were found to be associated with SB-T-12854 application. The pro-apoptotic Bad protein of the Bcl-2 family seems to be important for cell death induction by taxane SB-T-12854 in the tested cells. The anti-apoptotic Bcl-2 protein also seems to be associated with apoptosis induction in SK-BR-3 and MCF-7 cells and the pro-apoptotic Bim in MCF-7 and T47D cells. Similarly, the pro-apoptotic Bok in MCF-7 cells as well as the pro-apoptotic Bid and Bik in SK-BR-3 cells could be involved in apoptosis induction by SB-T-12854. The mitochondrial apoptotic pathway, after SB-T12854 application, was significantly activated in association with the release of cytochrome $c$ and Smac from mitochondria, but only in SK-BR-3 cells, and not in MCF-7 and T47D cells.

In summary, cell death induced by SB-T-12854 in the tested breast cancer cells differs with regard to the activation of caspases, changes in levels of pro-apoptotic as well as anti-apoptotic proteins of the Bcl-2 family, and release of pro-apoptotic factors (cytochrome $c$, Smac) from mitochondria into the cytosol.

\section{Acknowledgements}

This work was supported by research project PRVOUK P27 from the Charles University and by project GAUK 661012 from the Charles University, as well as by a grant from the National Institute of Health, U.S.A. (CA103314 to IO). 


\section{References}

1 Joshi M, Liu X and Belani CP: Taxanes, past, present, and future impact on non-small cell lung cancer. Anticancer Drugs 25(5): 571-583, 2014.

2 O'Reilly EA, Gubbins L, Sharma S, Tully R, Guang MH, Weiner-Gorzel K, McCaffrey J, Harrison M, Furlong F, Kell M and McCann A: The fate of chemoresistance in triple negative breast cancer (TNBC). BBA Clin 12(3): 257-275, 2015.

3 Kampan NC, Madondo MT, McNally OM, Quinn M and Plebanski M: Paclitaxel and its evolving role in the management of ovarian cancer. Biomed Res Int 2015: 413076, 2015.

4 George M, Ayoub AT, Banerjee A, Churchill CD, Winter P, Klobukowski M, Cass CE, Ludueña RF, Tuszynski JA and Damaraju S: Designing and Testing of Novel Taxanes to Probe the Highly Complex Mechanisms by Which Taxanes Bind to Microtubules and Cause Cytotoxicity to Cancer Cells. PLoS One 10(6): e0129168, 2015.

5 Huang S, Tang R and Poon RY: BCL-W is a regulator of microtubule inhibitor-induced mitotic cell death. Oncotarget 7(25): 38718-38730, 2016

6 Kováŕ J, Ehrlichová M, Šmejkalová B, Zanardi I, Ojima I and Gut I: Comparison of cell death-inducing effect of novel taxane SB-T-1216 and paclitaxel in breast cancer cells. Anticancer Res 29(8): 2951-2960, 2009.

7 Vobořilová J, Němcová-Fürstová V, Neubauerová J, Ojima I, Zanardi I, Gut I and Kováŕ J: Cell death induced by novel fluorinated taxanes in drug-sensitive and drug-resistant cancer cells. Invest New Drugs 29(3): 411-423, 2011.

8 Khongkow P, Gomes AR, Gong C, Man EP, Tsang JW, Zhao F, Monteiro LJ, Coombes RC, Medema RH, Khoo US and Lam EW: Paclitaxel targets FOXM1 to regulate KIF20A in mitotic catastrophe and breast cancer paclitaxel resistance. Oncogene 35(8): 990-1002, 2016

9 Ajabnoor GM, Crook T and Coley HM: Paclitaxel resistance is associated with switch from apoptotic to autophagic cell death in MCF-7 breast cancer cells. Cell Death Dis 26(3): e260, 2012.

10 Chumduri C, Gillissen B, Richter A, Richter A, Milojkovic A, Overkamp T, Müller A, Pott C and Daniel PT: Apoptosis resistance, mitotic catastrophe, and loss of ploidy control in Burkitt lymphoma. J Mol Med (Berl) 93(5): 559-572, 2015.

11 Tudor G, Aguilera A, Halverson DO, Laing ND and Sausville EA: Susceptibility to drug-induced apoptosis correlates with differential modulation of $\mathrm{Bad}, \mathrm{Bcl}-2$ and $\mathrm{Bcl}-\mathrm{xL}$ protein levels. Cell Death Differ 7(6): 574-586, 2000

12 Fauzee NJ, Wang YL, Dong Z, Li QG, Wang T, Mandarry MT, $\mathrm{Xu}$ L and Pan J: Novel hydrophilic docetaxel (CQMU-0519) analogue inhibits proliferation and induces apoptosis in human A549 lung, SKVO3 ovarian and MCF7 breast carcinoma cell lines. Cell Prolif 45(4): 352-364, 2012.

13 Luo Y, Wang X, Wang H, Xu Y, Wen Q, Fan S, Zhao R, Jiang S, Yang J, Liu Y, Li X, Xiong W, Ma J, Peng S, Zeng Z, Li X, Phillips JB, Li G, Tan M and Zhou M: High Bak expression is associated with a favorable prognosis in breast cancer and sensitizes breast cancer cells to paclitaxel. PLoS One 10(9): e0138955, 2015.

14 Calastretti A, Gatti G, Quaresmini C and Bevilacqua A: Downmodulation of Bcl-2 sensitizes PTEN-mutated prostate cancer cells to starvation and taxanes. Prostate 74(14): 1411-1422, 2014.
15 Sharifi S, Barar J, Hejazi MS and Samadi N: Roles of the Bcl2/Bax ratio, caspase- 8 and 9 in resistance of breast cancer cells to paclitaxel. Asian Pac J Cancer Prev 15(20): 8617-8622, 2014.

16 Ganansia-Leymarie V, Bischoff P, Bergerat JP and Holl V: Signal transduction pathways of taxanes-induced apoptosis. Curr Med Chem Anticancer Agents 3(4): 291-306, 2003.

17 Kutuk O and Letai A: Displacement of Bim by Bmf and Puma rather than increase in Bim level mediates paclitaxel-induced apoptosis in breast cancer cells. Cell Death Differ 17(10): 1624$1635,2010$.

18 Shuang T, Wang M, Shi C, Zhou Y and Wang D: Downregulated expression of miR-134 contributes to paclitaxel resistance in human ovarian cancer cells. FEBS Lett 589(20 Pt B): 3154-3164, 2015.

19 Song T, Chai G, Liu Y, Xie M, Chen Q, Yu X, Sheng H and Zhang Z: Mechanism of synergy of BH3 mimetics and paclitaxel in chronic myeloid leukemia cells: Mcl-1 inhibition. Eur J Pharm Sci 70: 64-71, 2015

20 Sunters A, Fernández de Mattos S, Stahl M, Brosens JJ, Zoumpoulidou G, Saunders CA, Coffer PJ, Medema RH, Coombes RC and Lam EW: FoxO3a transcriptional regulation of Bim controls apoptosis in paclitaxel-treated breast cancer cell lines. J Biol Chem 278(50): 49795-49805, 2003.

21 Savry A, Carre M, Berges R, Rovini A, Pobel I, Chacon C, Braguer D and Bourgarel-Rey V: Bcl-2-enhanced efficacy of microtubule- targeting chemotherapy through Bim overexpression: implications for cancer treatment. Neoplasia 15(1): 49-60, 2013.

22 Craik AC, Veldhoen RA, Czernick M, Buckland TW, Kyselytzia K, Ghosh S, Lai R, Damaraju S, Underhill DA, Mackey JR and Goping IS: The BH3-only protein Bad confers breast cancer taxane sensitivity through a nonapoptotic mechanism. Oncogene 29(39): 5381-5391, 2010.

23 Peng ZG, Liu DC, Yao YB, Feng XL, Huang X, Tang YL, Yang $\mathrm{J}$ and Wang XX: Paclitaxel induces apoptosis in leukemia cells through a JNK activation-dependent pathway. Genet Mol Res 15(1): 15013904, 2016.

24 Ehrlichová M, Koc M, Truksa J, Naldová Z, Václavíková R and Kovár J: Cell death induced by taxanes in breast cancer cells: cytochrome $\mathrm{C}$ is released in resistant but not in sensitive cells. Anticancer Res 25(6B): 4215-4224, 2005.

25 Luo Y, Ling Y, Guo W, Pang J, Liu W, Fang Y, Wen X, Wei K and Gao X: Docetaxel loaded oleic acid-coated hydroxyapatite nanoparticles enhance the docetaxel-induced apoptosis through activation of caspase- 2 in androgen independent prostate cancer cells. J Control Release 147(2): 278-288, 2010.

26 von Haefen C, Wieder T, Essmann F, Schulze-Osthoff K, Dörken B and Daniel PT: Paclitaxel-induced apoptosis in BJAB cells proceeds via a death receptor-independent, caspases-3/-8-driven mitochondrial amplification loop. Oncogene 22(15): 2236-2247, 2003.

27 Qin S, Zhang B, Xiao G, Sun X, Li G, Huang G, Gao X, Li X, Wang $\mathrm{H}$, Yang $\mathrm{C}$ and Ren $\mathrm{H}$ : Fibronectin protects lung cancer cells against docetaxel-induced apoptosis by promoting Src and caspase-8 phosphorylation. Tumour Biol 37(10): 13509-13520, 2016.

28 Vakifahmetoglu-Norberg $\mathrm{H}$ and Zhivotovsky $\mathrm{B}$ : The unpredictable caspase-2: what can it do? Trends Cell Biol 20(3): 150-159, 2010.

29 Mhaidat NM, Wang Y, Kiejda KA, Zhang XD and Hersey P: Docetaxel-induced apoptosis in melanoma cells is dependent on activation of caspase-2. Mol Cancer Ther 6(2): 752-761, 2007. 
30 Ho LH, Read SH, Dorstyn L, Lambrusco L and Kumar S: Caspase- 2 is required for cell death induced by cytoskeletal disruption. Oncogene 27(24): 3393-3404, 2008.

31 Jelínek M, Balušíková K, Kopperová D, Nĕmcová-Fürstová V, Šrámek J, Fidlerová J, Zanardi I, Ojima I and Kovář J: Caspase2 is involved in cell death induction by taxanes in breast cancer cells. Cancer Cell Int 13(1): 42, 2013.

32 Jelínek M, Balušíková K, Schmiedlová M, Němcová-Fürstová V, Šrámek J, Stančíková J, Zanardi I, Ojima I and Kovář J: The role of individual caspases in cell death induction by taxanes in breast cancer cells. Cancer Cell Int 15: 8, 2015.

33 Kopczyńska E: Role of microRNAs in the resistance of prostate cancer to docetaxel and paclitaxel. Contemp Oncol (Pozn) 19(6): 423-427, 2016.

34 Ojima I, Chen J, Sun L, Borella CP, Wang T, Miller ML, Lin S, Geng X, Kuznetsova L, Qu C, Gallager D, Zhao X, Zanardi I, Xia S, Horwitz SB, Mallen-St Clair J, Guerriero JL, Bar-Sagi D, Veith JM, Pera P and Bernacki RJ: Design, synthesis, and biological evaluation of new-generation taxoids. J Med Chem 51(11): 3203-3221, 2008.

35 Ferlini C, Raspaglio G, Mozzetti S, Cicchillitti L, Filippetti F, Gallo D, Fattorusso C, Campiani G and Scambia G: The seco-taxane IDN5390 is able to target class III beta-tubulin and to overcome paclitaxel resistance. Cancer Res 65(6): 2397-2405, 2005.

36 Galletti E, Magnani M, Renzulli ML and Botta M: Paclitaxel and docetaxel resistance: molecular mechanisms and development of new generation taxanes. ChemMedChem 2(7): 920-942, 2007.

37 Ojima I, Lichtenthal B, Lee S, Wang C and Wang X: Taxane anticancer agents: a patent perspective. Expert Opin Ther Pat 26(1): 1-20, 2016.

38 Botchkina GI, Zuniga ES, Das M, Wang Y, Wang H, Zhu S, Savitt AG, Rowehl RA, Leyfman Y, Ju J, Shroyer K and Ojima I: New-generation taxoid SB-T-1214 inhibits stem cell-related gene expression in 3D cancer spheroids induced by purified colon tumor-initiating cells. Mol Cancer 14(9): 192, 2010.

39 Pepe A, Kuznetsova L, Sun L and Ojima I: Fluoro-taxoid anticancer agents. In: Ojima I (ed) Fluorine in medical chemistry and chemical biology, 1st edn.Wiley-Blackwell, Chicheste pp. 117-139, 2009.
40 Friedrich K, Wieder T, Von Haefen C, Radetzki S, Jänicke R, Schulze-Osthoff K, Dörken B and Daniel PT: Overexpression of caspase-3 restores sensitivity for drug-induced apoptosis in breast cancer cell lines with acquired drug resistance. Oncogene 20(22): 2749-2760, 2001.

41 Musílková J and Kovář J: Additive stimulatory effect of extracellular calcium and potassium on non-transferrin ferric iron uptake by HeLa and K562 cells. Biochim Biophys Acta 1514(1): 117-126, 2001.

42 Otová B, Ojima I, Václavíková R, Hrdý J, Ehrlichová M, Souček P, Vobořilová J, Němcová V, Zanardi I, Horský S, Kovář J and Gut I: Second-generation taxanes effectively suppress subcutaneous rat lymphoma: role of disposition, transport, metabolism, in vitro potency and expression of angiogenesis genes. Invest New Drugs 30(3): 991-1002, 2012.

43 Němcová-Fürstová V, Kopperová D, Balušíková K, Ehrlichová M, Brynychová V, Václavíková R, Daniel P, Souček P and Kovár $\mathrm{J}$ : Characterization of acquired paclitaxel resistance of breast cancer cells and involvement of ABC transporters. Toxicol Appl Pharmacol 310: 215-228, 2016.

$44 \mathrm{Hu} \mathrm{Y,} \mathrm{Xu} \mathrm{K}$ and Yagüe E: miR-218 targets survivin and regulates resistance to chemotherapeutics in breast cancer. Breast Cancer Res Treat 151(2): 269-80, 2015.

45 Mac Fhearraigh S and Mc Gee MM: Cyclin B1 interacts with the $\mathrm{BH} 3$-only protein Bim and mediates its phosphorylation by Cdk1 during mitosis. Cell Cycle 10(22): 3886-3896, 2011.

46 Zhong Z, Chen X, Tan W, Xu Z, Zhou K, Wu T, Cui L and Wang $Y$ : Germacrone inhibits the proliferation of breast cancer cell lines by inducing cell cycle arrest and promoting apoptosis. Eur J Pharmacol 667(1-3): 50-55, 2011.

47 Ley R, Ewings KE, Hadfield K and Cook SJ: Regulatory phosphorylation of Bim: sorting out the ERK from the JNK. Cell Death Differ 12(8): 1008-1014, 2005.

Received January 31, 2017

Revised March 15, 2017

Accepted March 20, 2017 